\title{
DA NATUREZa À CULTURA: O PROBLEMA DA PROIBIÇÃO DO INCESTO NA ANTROPOLOGIA DE ROUSSEAU ${ }^{1}$
}

\author{
Mauro Dela Bandera ${ }^{2}$
}

\begin{abstract}
Resumo: A dicotomia mundo físico/mundo moral é característica do século XVIII francês. Refere-se às dimensões biológicas naturais e às dimensôes morais do homem. Muitos autores do Iluminismo desejaram retraçar a história conjectural ou as metamorfoses sucessivas que levaram à passagem do homem físico para o homem moral. Essa temática se faz também presente na obra de Rousseau, sendo percebida e traduzida por Lévi-Strauss como a passagem da natureza à cultura. A hipótese desenvolvida neste artigo é de que a inscrição da interdição do incesto - presente na obra de Rousseau - ocupa uma função e uma significação muito próximas das reflexões de Lévi-Strauss, observadas nas Estruturas elementares do parentesco. Como em Lévi-Strauss, essa proibição marca para Rousseau o início do processo de formação cultural, o instante fundador da cultura. Ela explicita de maneira privilegiada o ponto por meio do qual os processos culturais se distinguem da esfera natural, o momento em que o homem deixa de seguir o mero instinto e passa a respeitar princípios morais construídos socialmente.
\end{abstract}

Palavras-chave: Natureza. Cultura. Proibição do incesto. Rousseau. Lévi-Strauss.

\section{INTRODUÇÁO: A PASSAGEM DA NATUREZAÀ CULTURA}

A dicotomia mundo físico/mundo moral é característica do século XVIII. Refere-se às dimensóes biológicas naturais e às dimensôes morais do homem. Dados os dois termos, muitos autores do Iluminismo desejaram retraçar a história conjectural ou as metamorfoses sucessivas que levaram à passagem do homem físico para o homem moral. Essa temática se faz notar na obra de Rousseau como um todo. No entanto, seus livros focam elementos diferentes da questão, apresentando compreensôes distintas do movimento da passagem. A descrição do puro estado de natureza - também chamado de "primeiro" ou "verdadeiro estado de natureza" - ocupa grande parte do

\footnotetext{
${ }^{1}$ Uma versão preliminar deste artigo foi apresentada em nossa tese de doutorado (2018).

2 Professor de Filosofia da Universidade Federal do Acre (UFAC), Rio Branco, AC - Brasil. ID https:// orcid.org/0000-0002-9672-2483 E-mail: maurodelabandera@yahoo.com.br
}

https://doi.org/10.1590/0101-3173.2021.v44n1.21.p293

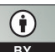

This is an open-access article distributed under the terms of the Creative Commons Attribution License. 
Discurso sobre a desigualdade, ao passo que as etapas dos desenvolvimentos humano e social são nele relatadas en passant. Interessa sobretudo o estado de quase imobilidade feliz.

No Contrato social, ao contrário, o foco principal de Rousseau é a descrição da esfera social; já no Ensaio sobre a origem das línguas o autor ocupase com o movimento de passagem de uma para outra esfera, apresentando a fronteira inatingível do quase: nem natureza nem sociedade (cultura), mas quase natureza e quase sociedade; momento breve no qual o homem, não pertencendo mais ao estado de pura natureza, mantém-se ainda aquém da sociedade (DERRIDA, 1967, p. 358-359).

A dicotomia físico/moral e suas derivaçóes ${ }^{3}$ norteiam o campo da antropologia, ao ser traduzida como a oposição natureza/cultura, o que nos remete diretamente à obra de Claude Lévi-Strauss. Aliás, foi esse autor que havia sinalizado a possibilidade de interpretar a obra de Rousseau pelo prisma da passagem da esfera natural à cultural. Nas páginas finais do Totemismo hoje - publicado em 1962 -, Lévi-Strauss (1995, p. 542-543) afirma:

[...] o Discurso sobre a origem e os fundamentos da desigualdade entre os homens é provavelmente o primeiro tratado de antropologia geral na literatura francesa. Em termos quase modernos, Rousseau coloca aí o problema central da antropologia, que é o da passagem da natureza para a cultura. Mais prudente que Bergson, ele tem o cuidado de náo invocar $o$ instinto que, pertencendo à ordem da natureza, náo teria possibilidade de ultrapassá-la. Antes que o homem se tornasse um ser social, o instinto de procriação, "tendência cega [...] somente produzia um ato puramente animal". ${ }^{4}$

Não convém discutir o pioneirismo de Rousseau ou se ele realmente elaborou o "primeiro tratado de antropologia geral na literatura francesa". Antes, o que pretendemos sublinhar nestas páginas é que o tema antropológico

\footnotetext{
${ }^{3}$ Tais como universal e particular, objetivo e subjetivo, fato e valor, dado e constituído, corpo e espírito, animalidade e humanidade, instinto e razão, sensação e reflexão, e tantos outros pares dicotômicos.

${ }^{4}$ Esse mesmo trecho é encontrado, com ligeiras alteraçóes, em outro texto de Lévi-Strauss. No mesmo ano da publicação do Totemismo hoje, 1962, Lévi-Strauss pronunciou um discurso - por conta das comemoraçóes do $250^{\circ}$ aniversário de nascimento de Rousseau - sustentando que "Rousseau não se limitou a prever a etnologia: ele a fundou. Inicialmente de modo prático, escrevendo este Discurso sobre a origem e os fundamentos da desigualdade entre os homens que coloca o problema das relaçôes entre a natureza e a cultura, e onde se pode ver o primeiro tratado de etnologia geral. Em seguida, no plano teórico, distinguindo, com uma clareza e uma concisão admiráveis, o objetivo próprio do etnólogo." (LÉVI-STRAUSS, 1996, p. 46-47).
} 
da (tríplice) passagem da natureza à cultura, da animalidade à humanidade e da afetividade à intelectualidade, se encontra presente tanto no Discurso sobre a desigualdade quanto no Ensaio. Nesses dois textos, o autor coloca ao leitor o problema central da antropologia. Dito isto, propomo-nos, neste artigo, discutir a passagem da ordem da natureza à ordem cultural, isto é, da vida puramente instintiva e do impulso físico à moralidade, tal como pensada por Rousseau em seus textos. Para tanto, as reflexôes sobre a proibição do incesto se revelarão fundamentais.

As questóes formuladas por Lévi-Strauss, no início das Estruturas elementares do parentesco (1949), guiarão aqui nossas reflexôes. Nesse livro, Lévi-Strauss se perguntava: "Onde acaba a natureza? Onde começa a cultura?" (LÉVI-STRAUSS, 1967, p. 4). Tais indagaçôes poderiam muito bem ter passado pela pena de Rousseau, precisamente no momento em que ele questiona: onde acaba o homem natural e onde começa o homem do homem (o homem moral e/ou cultural), isto é, o homem alterado e modificado pela sucessão do tempo e das coisas?

\section{História CONJECTURAL DA PASSAGEM DA NATUREZa À CULTURA}

Para entender a passagem da natureza à cultura, Lévi-Strauss principia oferecendo respostas negativas que elencam alguns dos meios concebidos pela tradição: i) isolar uma criança recém-nascida e observar suas reaçóes a diferentes excitaçóes; ii) o caso das crianças-selvagens (homo ferus) explorado por um sem número de autores; ou, ainda, iii) observar nos níveis superiores da vida animal atitudes e manifestaçóes nas quais se possam reconhecer o esboço ou os sinais precursores da cultura, como o caso dos mamíferos superiores, particularmente os macacos antropoides (homo sylvestris). ${ }^{5}$ De acordo com o antropólogo, todos esses meios se mostraram "[...] singularmente decepcionantes." (LÉVISTRAUSS, 1967, p. 4).

Lévi-Strauss é levado a reconhecer que nenhuma análise real ou calcada na experiência permite apreender o ponto da passagem entre os fatos da natureza e os da cultura. Mas, aos seus olhos, mesmo na falta de uma significação histórica aceitável, a distinção entre estado de natureza e estado

5 No século XVIII, podemos pensar como exemplos dessas metodologias de pesquisa os projetos experimentais imaginados por Maupertuis, como aquele de reunir, desde a mais tenra idade, crianças sem nenhum comércio com outros homens, a fim de estudar o nascimento da língua e das ideias no estado puro (MAUPERTUIS, 1980, p. 170-171); também podemos citar os numerosos estudos sobre o Homo sylvestris e o Homo ferus, tais como os de Condillac, La Mettrie, Buffon, Rousseau e tantos outros. 
de sociedade/cultura ainda se mostra relevante, pois é capaz de apresentar um valor lógico que justifica plenamente sua utilizaçáo como instrumento de método. É preciso, então, procurar a passagem em uma análise ideal para a qual é necessário encontrar critérios que possibilitem - ao menos em certos casos e em certos limites - isolar os elementos naturais dos elementos culturais que intervêm nas sínteses de ordem mais complexa.

Um primeiro paralelo, ainda bastante superficial, delineia-se aqui entre a obra do antropólogo e o Discurso sobre a desigualdade de Rousseau. Ele diz respeito às suas respectivas metodologias. De forma análoga ao que se passa em Lévi-Strauss, Rousseau também escapa de uma explicação calcada em uma gênese real. Mesmo sendo um dos autores do século XVIII que abordou e analisou as figuras das crianças-selvagens, que confeccionou longas passagens sobre o estatuto dos orangotangos (ROUSSEAU, OCIII, 1964, p. 196-198 e p. 208-214) e que, no Emílio, mostrou a formação progressiva do entendimento humano individual, podemos dizer que algo análogo à metodologia de LéviStrauss se esboça em seu livro.

É sabido que a redação do Discurso sobre a desigualdade pretende responder à seguinte questão proposta pela academia de Dijon: qual é a origem da desigualdade entre os homens; e será que ela é autorizada pela natureza? Para tanto, Rousseau procura elaborar a imagem hipotética do homem "[...] tal como a natureza o formou" (ROUSSEAU, OC III, 1964, p. 122), despindo-o de todos os atributos que as circunstâncias e os progressos humanos acrescentaram a seu estado primitivo. No prefácio de seu Discurso, o autor afirma com clareza seu objetivo, sem se importar com a experiência histórica concreta:

Separar o que há de original e de artificial na natureza atual do homem e conhecer com exatidáo um estado que não mais existe, que talvez nunca tenha existido, que provavelmente jamais existirá e sobre o qual se tem, contudo, a necessidade de alcançar noções exatas para bem julgar de nosso estado presente. (ROUSSEAU, OC III, 1964, p. 123). ${ }^{6}$

Rousseau se esforça, pois, em animalizar o ser humano -, contudo, sem jamais reduzi-lo à condição de animal nem sequer a um nível em que seja impossível distingui-lo dos animais -, tornando-o incapaz de realizar certos tipos de operaçôes mentais e técnicas que o homem social, já afastado do

${ }^{6}$ Podemos ler também, na Carta a Christophe de Beaumont, o seguinte: "[...] esse homem não existe, você dirá; que seja! Mas ele pode existir por suposição.” (ROUSSEAU, OC IV, 1969, p. 952). 
puro estado de natureza, pode efetuar. O método verificado no Discurso sobre a desigualdade foi chamado por Starobinski de antropologia negativa: "[...] o homem natural define-se pela ausência de tudo que pertence especificamente à condição do homem civilizado. [...] É então por uma espécie de "via negativa' que ele [Rousseau] procura traçar a imagem do homem da natureza." (STAROBINSKI, 1991, p. 314).

Seguindo um caminho aberto pelas reflexões de Condillac, Rousseau almeja, com seu método antropológico, demonstrar que tudo o que a tradição definira como original da natureza humana é, na verdade, obra humana e historicamente adquirido, possuindo assim uma gênese: a linguagem articulada, a aquisição e o domínio do fogo, a família, a sociedade, a propriedade, a racionalidade, a moralidade, as regras formais do direito e tantas outras coisas. Com isso, ele pretende indicar que a natureza náo preparou o homem para a sociedade e que, por conseguinte, os inconvenientes e os defeitos desta não estão irremediavelmente arraigados naquela.

Em nenhum momento da investigação é colocada a questão da existência real e histórica do estado de natureza, nem, por conseguinte, do percurso narrado. Não importa se ele existe ou existiu realmente, basta existir por suposição. $\mathrm{O}$ "estado de animalidade" (ROUSSEAU, OC III, 1964, p. 217) ou o "puro estado de natureza" se situa fora do tempo e fora da história, mas seu estatuto se afirma enquanto condição necessária para narrar a história hipotética dos homens. Não se deve, declara Rousseau (OC III, 1964, p. 132-133),

[...] considerar as pesquisas, em que se pode entrar neste assunto como verdades históricas, mas somente como raciocínios hipotéticos e condicionais, mais apropriados a esclarecer a natureza das coisas do que a mostrar a verdadeira origem, e semelhantes àquelas que, todos os dias, fazem nossos físicos sobre a formação do mundo.

O autor elabora uma imagem ideal do homem natural e uma do estado de natureza que sejam próprias para esclarecer a natureza das coisas, bem como a transiçáo do estado de natureza para o estado de sociedade. Ele não pretende em absoluto verificar a origem concreta dessa transição. Interessalhe a elaboração de um método capaz de interpretar o estado atual das coisas. Para confeccionar esse método, o Discurso sobre a desigualdade começa por "afastar todos os fatos" (ROUSSEAU, OC III, 1964, p. 132) e anuncia o abandono dos "livros científicos", uma vez que eles não se prendem à questão 
(ROUSSEAU, OC III, 1964, p. 125). ${ }^{7}$ Rousseau então estabelece o ponto de vista do hipotético estado de natureza sobre a sociedade, de modo a submeter o fenômeno social ao crivo de uma análise que o examina a partir do que seria seu contraste e seu negativo. Com base no ideal formulado de estado de natureza, busca-se construir uma crítica do estado presente. Assim, mesmo que o puro estado de natureza não tenha lugar na história, é preciso defini-lo, sendo ele a referência em função da qual se poderá julgar a condição social.

A passagem da ordem natural à ordem cultural ou do mundo físico ao mundo moral realiza-se no plano hipotético-teórico e não no históricoconcreto, sendo que o próprio Rousseau admitira a possibilidade de se estabelecer raciocínios hipotéticos ou "formar conjecturas" (ROUSSEAU, OC III, 1964, p. 133). O autor sustenta que, na ausência dos fatos ou quando eles nada explicam, cabe à filosofia propor uma história possível dos fenômenos. Alguns intérpretes chamam esse método de "história conjectural" (WOKLER, 1995) ou ficção filosófica (CHARRAK, 2014). ${ }^{8}$ Fiquemos, por comodidade, com a ideia de história conjectural. Trata-se de um método de exposição e também de conhecimento que visa, por meio da narrativa de processos possíveis que dáo nascimento a tal coisa ou fenômeno (como a sociedade, a desigualdade, o direito, a linguagem etc.), a explicar sua natureza. No entanto, se o discurso de Rousseau assume deliberadamente o estatuto conjectural, a abordagem conjectural por si só não invalida o conhecimento. $\mathrm{O}$ que o invalida é uma conjectura vaga, gratuita e de má fé.

Nesse sentido, há sim uma verdadeira história em Rousseau, mesmo se uma história filosófica, hipotética ou conjectural. Ela possui como ponto de partida as ideias de liberdade e perfectibilidade. Rousseau distingue metafisicamente a humanidade da animalidade, através desses dois predicados exclusivos: os homens são agentes livres não entregues à fixidez do instinto

\footnotetext{
7 Rousseau, que leu tantos livros, nos convida constantemente a afastá-los todos. "Fechei todos os livros", diz o Vigário (Rousseau, OC IV, 1969, p. 624); “[...] procurei a verdade nos livros, encontrei somente a mentira e o erro", lemos na Carta a Beaumont (ROUSSEAU, OC IV, 1969, p. 967); na Carta sobre a virtude, o autor afirma: "[...] deixe todos os livros" (ROUSSEAU, OC XVII, p. 314, version électronique: http://rousseau.slatkine.com/). No entanto, é preciso investigar se Rousseau realmente afasta os fatos científicos no Discurso sobre a desigualdade, já que as notas do texto formigam de referências a conteúdos de história natural, anatomia comparada, relatos dos viajantes etc.

8 Ver também Charrak (2013, p. 24), além da introdução que esse mesmo autor escreveu para sua ediçấo do Emílio (CHARRAK. In: ROUSSEAU, 2009, p. 9 e 18) e, ainda, Ehrard (1994, p. 751).
} 
e perfectíveis, ao passo que os animais são condenados a seguir o instinto próprio de sua espécie e a permanecer sempre idênticos a si mesmos. ${ }^{9}$

Apesar de distintas, liberdade e perfectibilidade aparecem intimamente associadas, de modo que podemos sustentar que a perfectibilidade - vista como relativa, pois inscrita no tempo e submetida ao mundo - deve ser encarada como o índice ou o sintoma da liberdade - centro absoluto. Esses dois predicados juntos fazem com que a natureza humana inscreva em si mesma a possibilidade de sair do mundo natural, lançando o ser humano ao universo da cultura. Em suma, a natureza humana é irredutivelmente histórica. A liberdade e a perfectibilidade se tornam os princípios de uma antropologia do desenvolvimento e da alteração em Rousseau, portanto, de uma história.

Mesmo que os objetivos de Rousseau não sejam os mesmos dos vislumbrados por Lévi-Strauss, nas Estruturas elementares do parentesco, as metodologias por eles utilizadas para explicar a passagem da natureza à cultura guardam entre si certas analogias: na impossibilidade de se alcançar uma explicação calcada em uma experiência real, ambos forjam mecanismos metodológicos situados no plano ideal para tentar entender a passagem. Como veremos a partir de agora, a análise sobre a proibição do incesto exercerá um papel similar nas teorias de ambos os autores sobre a compreensão dessa passagem.

\section{A PROIBIÇÁO dO INCESTO}

Deixando de lado esse primeiro paralelo metodológico, podemos identificar outro que diz respeito não mais ao Discurso sobre a desigualdade, mas sim ao Ensaio sobre a origem das linguas. Sabemos que a proibição do incesto tem um papel nuclear no desenrolar da argumentação de Lévi-Strauss acerca do momento da passagem da natureza para a cultura. Tal proibição é justamente o operador metodológico que permite isolar e articular os elementos naturais e os elementos culturais. Essa interdição também figura - é verdade que de

\footnotetext{
9 Como analisamos em outra ocasião (BANDERA, 2019), a perfectibilidade não é e nunca poderia ser considerada virtual ou em potência, pois, na ausência de instinto fixo, ela opera desde o primeiro estado de natureza. Os humanos dispersos entre os animais "[...] observam, imitam sua indústria e se elevam assim até o instinto dos bichos, com a vantagem que cada espécie tem somente o seu próprio e que o homem", por ser caracterizado enquanto um agente livre, "[...] não tendo talvez nenhum que lhe pertença, se apropria de todos.” (ROUSSEAU, OC III, 1964, p. 135). Tal apropriação é precisamente a perfectibilidade em ação. Em um primeiro momento, o homem é menos que o animal, posteriormente, pela observação e a imitação, ele se iguala ao animal para, finalmente, ultrapassá-lo.
} 
maneira bastante discreta - no Ensaio de Rousseau, mais especificamente em uma nota do capítulo IX. Contudo, ainda não se determinou com segurança qual é seu significado, nem qual é sua posição nas reflexôes do autor.

Se, para o antropólogo, tal interdição ocupa um lugar central em suas reflexôes, o mesmo não ocorre em Rousseau. A despeito disso, a hipótese que desenvolveremos é que a inscrição dessa interdição ocupa no Ensaio uma função e uma significação muito próximas do que se passa nas reflexôes de Lévi-Strauss.

Para bem compreender o sentido da passagem da natureza à cultura e melhor situar a inscrição da regra que proíbe o incesto, na economia do Ensaio, recorreremos à obra de Lévi-Strauss. Não pretenderemos defender a hipótese de Rousseau como um predecessor do pensamento do etnólogo moderno ${ }^{10}$, confundindo dois registros epistemológicos distintos, porém, mobilizar uma chave de leitura capaz de lançar alguma luz sobre aspectos da teoria rousseauniana. Desnecessário dizer que tampouco pretendemos fazer uma análise exaustiva dos problemas levantados e propostos por Lévi-Strauss. Limitaremos nossa análise a recolher alguns elementos teóricos de seu trabalho, a fim de melhor compreender a filosofia de Rousseau. Sobre a questão aqui em debate - a função da proibição do incesto para a inteligibilidade da passagem da natureza à cultura em Rousseau -, a obra de Lévi-Strauss se revela boa para pensar.

Nesse sentido, como é anunciada e para onde aponta a proibição do incesto, nas páginas do Ensaio sobre a origem das linguas? Citemos:

Havia famílias, mas não havia nações; havia línguas domésticas, mas nenhuma língua popular; havia casamentos, mas não amor. Cada família bastava-se a si mesma e perpetuava-se unicamente pelo sangue; os filhos nascidos dos mesmos pais cresciam juntos e aos poucos encontravam meios de se explicarem entre si; os sexos com a idade se distinguiam, a inclinaçâo natural era suficiente para uni-los, o instinto ocupava o lugar da paixão, o hábito o da preferência, passava-se a marido e esposa sem deixar de ser irmão e irmã $\tilde{a}^{*}$ Não havia nisso nada de muito estimulante para desembrulhar a língua, nada que pudesse com bastante frequência arrancar os acentos

${ }^{10} \mathrm{O}$ próprio Lévi-Strauss reconhece muito mais do que uma simples inspiração rousseauísta em seu ofício. Conforme já frisamos, Lévi-Strauss afirmara que Rousseau fundou a etnologia. Citemos: "Rousseau não foi somente um observador penetrante da vida campestre, um leitor apaixonado dos livros de viagem, um analista atento dos costumes e das crenças exóticas: sem receio de ser desmentido, pode-se afirmar que ele havia concebido, querido e enunciado a etnologia um século inteiro antes que ela fizesse sua aparição, colocando-a, de pronto, entre as ciências naturais e humanas já constituídas." (LÉVI-STRAUSS, 1996, p. 45). 
das paixões ardentes a fim de transformá-los em instituições e o mesmo se pode dizer das necessidades raras e pouco exigentes que poderiam levar certos homens aos trabalhos comuns. (ROUSSEAU, OC V, 1995, p. 406407, grifos nossos).

* Foi preciso que os primeiros homens desposassem suas irmãs. Na simplicidade dos primeiros costumes, esse uso se perpetuou sem inconvenientes enquanto as famílias permaneceram isoladas, e mesmo depois da reuniáo dos povos mais antigos. A lei que o aboliu, no entanto, não é menos sagrada por ser de instituição humana. Aqueles que só a consideram pelo liame que forma entre as famílias não veem seu aspecto mais importante. $\mathrm{Na}$ familiaridade que o comércio doméstico necessariamente estabelece entre os dois sexos, a partir do momento em que uma lei táo santa deixasse de falar ao coração e de impor-se aos sentidos, não haveria mais honestidade entre os homens e os mais terríveis costumes logo determinariam a destruição do gênero humano. (nota do autor).

Rousseau insiste para não se considerar apenas a ligação que a proibição do incesto "forma entre as famílias". Como ressaltaremos, essa ligação e a socialização entre as famílias supóem a interdição. Entretanto, existem para o autor outros elementos mais importantes. A interdição assume um aspecto moral, sem o qual "[...] não haveria mais honestidade entre os homens e os mais terríveis costumes logo determinariam a destruição do gênero humano.” É difícil conjecturar como se daria essa destruição do gênero humano, na medida em que o próprio autor afirmara, linhas antes, que "[...] esse uso se perpetuou sem inconvenientes [...] mesmo depois da reunião dos povos mais antigos", limitando de certa maneira essa lei.

O que seguramente podemos sustentar - tal é o objetivo destas páginas - é que a proibição do incesto não engendra apenas uma mera ligação entre as famílias, mas sim a ligação moral, isto é, a passagem da ordem física e natural (leia-se animalidade) à ordem moral e cultural (leia-se humanidade). Trata-se, assim, da própria armação ou ordem social, diferente de uma aglomeração ou agrupamento natural baseado nas inclinaçôes naturais, no hábito ou no instinto. Sem ela, o gênero humano poderia ser destruído, se entendermos essa destruição como a ausência do social e da ordem moral.

Jacques Derrida, na Gramatologia, comenta o excerto supracitado do Ensaio, enfatizando que, se a proibição do incesto "[...] é afirmada sagrada ${ }^{11}$

11 "Em geral, Rousseau só atribui o caráter de sagrado, de santidade, à voz natural que fala ao coração, à lei natural que é a única a inscrever-se no coração. Só é sagrada aos seus olhos uma única instituição, uma única convenção fundamental: é, diz-nos o Contrato social, a própria ordem social, o direito do 
apesar de instituída, é por ser, apesar de instituída, universal.” Nesse sentido, se, por um lado, Rousseau acrescenta em sua descrição alguns fatos que deveriam limitar essa santa lei, ao asseverar que o uso de desposar irmãs ainda teve certa continuidade, por outro, é a ordem universal da cultura que está em jogo, quando a proibição do incesto entra em cena. "Rousseau", continua Derrida, "[...] só consagra a convenção sob uma condição: que se possa universalizá-la e considerá-la, ainda que fosse o artifício dos artifícios, como uma lei quase natural, conforme a natureza." (DERRIDA, 1967, p. 374).

Nas páginas das Estruturas elementares do parentesco, Lévi-Strauss também afirma o “[...] caráter sagrado da proibição" (LÉVI-STRAUSS, 1967, p. 14). Não obstante, o ponto que gostaríamos de salientar é que Lévi-Strauss defende a tese de que somente os homens são capazes de viver de acordo com normas; distinguem-se dos animais a partir de uma capacidade normativa. Com base na dicotomia universal/particular, o autor separa os elementos pertencentes à natureza daqueles que participam da esfera cultural. Citemos:

Em toda parte onde se manifesta uma regra podemos ter certeza de estar em uma etapa da cultura. Simetricamente, é fácil reconhecer no universal o critério da natureza. Porque aquilo que é constante em todos os homens escapa necessariamente ao domínio dos costumes, das técnicas e das instituiçōes pelas quais seus grupos se diferenciam e se opóem. [...] Estabeleçamos, pois, que tudo quanto é universal no homem depende da ordem da natureza e se caracteriza pela espontaneidade, e que tudo quanto está ligado a uma norma pertence à cultura e apresenta os atributos do resultado particular. (LÉVI-STRAUSS, 1967, p. 10).

Nessa perspectiva, a ordem da natureza é aquela na qual o homem se encontra enquanto um ser, por assim dizer, biológico. Suas respostas a estímulos externos ou internos dependem apenas de sua natureza, de seu instinto ou de seu apetite. Assim, podemos estabelecer que tudo aquilo que é universal no homem, ou seja, tudo aquilo que acontece com todos os outros e em todos os lugares e tempos pertence à esfera da natureza. $\mathrm{O}$ exato contrário se passa com a ordem da cultura: aquilo que é fruto de uma instituição humana ou de uma norma caracteriza-se pela particularidade e pertence ao âmbito da cultura. Portanto, a presença da regra nos comportamentos náo sujeitos às determinaçôes instintivas é o critério mais válido para se decidir o que faz

direito, a convenção que serve de fundamento a todas as convençôes: a ordem social é um direito sagrado que serve de base a todos os outros. Contudo, esse direito nâo vem em absoluto da natureza; é fundado, pois, em convenção." (DERRIDA, 1967, p. 373-374). 
parte das atitudes culturais. Quando da existência de uma regra, estamos diante de um processo cultural, ao passo que entrevemos em sua ausência um processo natural.

Posto isso, para se determinar o limite entre natureza e cultura, é preciso procurar uma regra que está presente em todas as culturas, pois somente assim se chegará àquilo que define o início do processo de formação cultural. Essa regra, segundo Lévi-Strauss, é justamente a proibiçáo do incesto, já que seu duplo caráter - um na ordem da natureza e outro na ordem da cultura - faz com que ela seja o marco da passagem de uma para outra estrutura. Em outras palavras, a proibição do incesto está localizada em uma zona cinzenta de difícil demarcação: é, ao mesmo tempo, natureza e cultura, ou, ainda, uma regra válida universalmente. Por isso, ela

[...] constitui o passo fundamental graças ao qual, pelo qual, mas sobretudo no qual se realiza a passagem da natureza à cultura. Em certo sentido pertence à natureza, porque é uma condição geral da cultura e, por conseguinte, não devemos nos espantar em vê-la conservar da natureza seu caráter formal, isto é, a universalidade. Mas em outro sentido também já é cultura, agindo e impondo sua regra no interior de fenômenos que não dependem primeiramente dela. (LÉVI-STRAUSS, 1967, p. 29).

Explica-se por que a proibição do incesto é considerada, para o autor das Estruturas elementares do parentesco, o ponto de passagem da natureza à cultura. Existe natureza e existe cultura, a proibição do incesto faz a transição entre elas.

Antes dela a cultura ainda não está dada. Com ela a natureza deixa de existir, no homem, como um reino soberano. A proibição do incesto é o processo pelo qual a natureza se ultrapassa a si mesma. Acende a faísca sob a ação da qual forma-se uma estrutura de novo tipo, mais complexa. (LÉVI-STRAUSS, 1967, p. 29).

Esses desenvolvimentos teóricos de Lévi-Strauss se aproximam do excerto citado do Ensaio sobre a origem das linguas. De acordo com Rousseau, a lei que aboliu o costume de desposar irmãs "[...] não é menos sagrada por ser de instituição humana." Se, por um lado, a lei é sacra e expressa uma aspiração de universalidade, por outro, ela é fruto de uma instituição, uma norma particular criada por um grupo social determinado. Em outras palavras, Rousseau também reconhece o caráter ambíguo da regra que proíbe o incesto: 
é uma instituição humana, por se tratar de uma regra, mas, em contrapartida, é a única dentre todas as regras sociais que possui um caráter de universalidade, como se fizesse parte da natureza.

A partir disso, podemos até mesmo conjecturar algumas similaridades mais profundas entre os dois autores, no que se refere à posição e à significação da regra que interdita o incesto. Como em Lévi-Strauss, essa proibição marca no Ensaio de Rousseau o início do processo de formação cultural. Ela explicita, de maneira privilegiada, o ponto por meio do qual os processos culturais marcados pelo surgimento da "paixão" e da preferência" - se distinguem da esfera natural - caracterizados pelo "instinto", "hábito" e "inclinação natural". Vejamos em pormenor como essa passagem se realiza, nas páginas do livro de Rousseau. Para tanto, será necessário realizar algumas distinçóes teóricas entre as duas narrativas hipotéticas do autor (o Discurso sobre a desigualdade e o Ensaio).

Antes da proibição do incesto, o Ensaio retrata um momento de organização pré-social que precede a eclosão das paixôes e, por conseguinte, o despertar das línguas. $\mathrm{O}$ que chama a atenção do leitor - especialmente daquele habituado com as páginas do Discurso sobre a desigualdade - é a noção de família mobilizada por Rousseau. Nas páginas do Ensaio, a família é uma unidade estável, mas uma "[...] unidade puramente biológica, sem nenhum laço moral, sem proibição do incesto, sem palavra” (MOSCONI, 1966, p. 75), ao passo que, no Discurso sobre a desigualdade, o conceito de família é definido de modo diferente. Citemos primeiramente o Discurso:

Entrevemos aqui um pouco melhor como o uso da palavra se estabelece ou se aperfeiçoa imperceptivelmente no seio de cada família e podemos ainda conjecturar como diversas causas particulares puderam estender a linguagem e acelerar-lhe o progresso, tornando-a mais necessária. Grandes inundaçôes ou tremores de terra cercaram de água ou de precipícios regióes habitadas; revoluçóes do globo separaram e cortaram em ilhas porçóes do continente. Concebe-se que, entre homens aproximados desse modo e forçados a viverem juntos, deve ter se formado um idioma comum, mais facilmente do que entre aqueles que erravam livremente nas florestas da terra firme. [...] É pelo menos bastante verossímil que a sociedade e as línguas tenham nascido nas ilhas e aí se aperfeiçoado antes de serem conhecidas no continente. (ROUSSEAU, OC III, 1964, p. 168-169, grifos nossos). 
Também no Ensaio, a união ou a associação entre os homens é resultado de "acidentes da natureza" como, por exemplo, dilúvios, erupçôes vulcânicas, terremotos, incêndios e tantas outras coisas (ROUSSEAU, OCV, 1995, p. 402). Apesar da semelhança entre os dois livros, o Discurso sobre a desigualdade deixa entrever que o uso da palavra se estabeleceu ou se aperfeiçoou "no seio de cada família", só se estendendo ou progredindo posteriormente - quando "diversas causas particulares” ou catástrofes naturais aproximaram os homens -, ao passo que o Ensaio não considera as línguas domésticas verdadeiras línguas. A diferença reside na própria noçáo de família mobilizada nos dois textos.

"No Discurso, a 'pequena sociedade' familiar, fundada sobre a afeição, é o lugar dos 'primeiros desenvolvimentos do coração' e da origem da palavra." (MOSCONI, 1966, p. 75). Com as cabanas e a coabitação entre homem e mulher, entra em cena o amor conjugal e o amor paternal/maternal fundado na convivência comum num mesmo espaço determinado. Não se trata, nesse momento, do amor exogâmico ou do amor enquanto paixão ardente e arrebatadora, mas de um amor sereno, calcado no hábito, na regularidade e na afeição recíproca. Citemos Rousseau (OC III, 1964, p. 168, grifo nosso):

Os primeiros desenvolvimentos do coração decorreram de uma situação nova que reunia numa habitação comum os maridos e as mulheres, os pais e os filhos. $O$ hábito de viver junto fez nascer os mais doces sentimentos porventura conhecidos pelos homens, o amor conjugal e o amor paterno. Cada família tornou-se uma pequena sociedade ainda mais unida por serem o apego recíproco e a liberdade os seus únicos vínculos.

Já no Ensaio, os primeiros desenvolvimentos do coração que dão origem à palavra acontecem por conta do comércio entre diferentes famílias. Nas regiôes do Sul, por exemplo, o calor e a aridez atraem os homens para os pontos de água. Esse encontro engendra sentimentos doces e voluptuosos entre membros de grupos familiares distintos, tal como foi ilustrado pela passagem das primeiras festas - frequentemente citada pelos comentadores como uma das mais belas produzidas por Rousseau (OC V, 1995, p. 405-406, grifos nossos):

Aí se formaram os primeiros laços de famílias e aí se deram os primeiros encontros entre os dois sexos. As moças vinham buscar água para o trabalho doméstico, os jovens vinham dar de beber aos rebanhos. Aí olhos acostumados desde a infância a ver os mesmos objetos começaram a ver outros mais agradáveis. O coração animou-se diante desses novos objetos, uma atraçáo desconhecida tornou-o menos selvagem, ele sentiu o prazer 
de não estar só. A água insensivelmente se tornou mais necessária, o gado teve sede com maior frequência: chegava-se apressadamente e partia-se com pesar. [...] Sob velhos carvalhos, vencedores dos anos, uma ardente juventude esquecia gradativamente sua ferocidade. Acostumaram-se, pouco a pouco, uns aos outros e, esforçando-se por se fazerem entender, aprenderam a explicar-se. Aíse realizaram as primeiras festas: os pés pulavam de alegria, o gesto pressuroso náo bastava mais, a voz acompanhava-o com acentos apaixonados; o prazer e o desejo confundidos faziam-se sentir ao mesmo tempo. Tal foi, enfim, o verdadeiro berço dos povos - do puro cristal das fontes saíram as primeiras chamas do amor.

A necessidade fazia com que as pessoas se reunissem ao redor dos pontos de água, o que não significa, de forma alguma, afirmar que foram as necessidades as responsáveis por fazerem os homens falarem. Elas foram responsáveis por estreitarem os laços sociais, por aproximarem famílias diferentes. $\mathrm{Na}$ passagem acima, observamos com clareza que foi o convívio comum (de diferentes famílias), no mesmo espaço, que propiciou a centelha do amor e da paixão, responsáveis por arrancar as primeiras vozes. As paixóes aproximam moralmente homens que outras necessidades já reuniram fisicamente e, aos poucos, “[...] o prazer de estar juntos, o desejo de se fazer amar, substituíram-se à necessidade de realizar tarefas materiais indispensáveis à sobrevivência." (CHANTELOUBE, 2003, p. 127).

Manifestam-se diferenças consideráveis, na textura conceitual das duas narrativas hipotéticas de Rousseau, pelo menos no que tange à noção de família nelas mobilizada. Se, no Discurso sobre a desigualdade, o hábito de viver junto na "sociedade conjugal" (ROUSSEAU, OC III, 1964, p. 217) fez nascer os mais doces sentimentos, estabelecendo o uso da palavra no "seio de cada família", no Ensaio, por sua vez, o hábito não tem "nada de muito estimulante para desembrulhar a língua”, ou ainda, acrescenta Rousseau, "[...] nada que pudesse com bastante frequência arrancar os acentos das paixóes ardentes a fim de transformá-los em instituiçóes.” Foi necessário, portanto, romper esse hábito para que "[...] olhos acostumados desde a infância a ver os mesmos objetos" começassem a ver "outros mais agradáveis". Com a introdução desses novos objetos, despontam-se finalmente as paixóes responsáveis por arrancar as primeiras palavras. ${ }^{12}$

\footnotetext{
${ }^{12}$ A continuação do excerto citado do Discurso volta a se aproximar das reflexôes presentes no Ensaio. Esse livro apresenta as primeiras festas nascendo do encontro entre os dois sexos (jovens de famílias distintas); do mesmo modo, o Discurso exibe os laços engendrados pela convivência entre grupos familiares distintos: "Uma vizinhança permanente não pode deixar de, afinal, engendrar algumas
} 
Rousseau expóe uma breve teoria da comparação, do conhecimento, da piedade e das afeiçôes sociais nas páginas iniciais do capítulo IX do Ensaio. ${ }^{13}$ Tais desenvolvimentos são fundamentais para a inteligibilidade do trecho citado das "primeiras festas". Segundo ele, o isolamento e a ignorância dos homens e das famílias produziam o medo e a ferocidade, consolidando assim o isolamento inicial. São necessários certos desenvolvimentos intelectuais para o surgimento da piedade e das afeições sociais, como o florescimento da imaginação e da reflexão. A comparação é, sob todos aspectos, fundamental. Ela só acontece quando uma multiplicidade de objetos novos afetam os sentidos. Assim, o hábito de sempre olhar as mesmas coisas impede a comparação. Citemos:

[...] a reflexão nasce das ideias comparadas e é a pluralidade das ideias que
leva à comparação. Quem vê um único objeto não pode fazer comparaçôes.
Quem vê somente um pequeno número de objetos e, desde a infância,
sempre os mesmos, também não os compara, pois o hábito de vê-los lhe
retira a atenção necessária para examiná-los. Mas à medida que um objeto
novo nos impressiona, queremos conhecê-lo e procuramos relaçóes entre
ele e os que já conhecemos. Assim, aprendemos a conhecer o que está
sob nossos olhos e somos levados, pelo que nos é estranho, a examinar

ligaçōes entre as famílias. Jovens de diferentes sexos habitam cabanas vizinhas, o comércio passageiro exigido pela natureza logo induz a outro, não menos doce e mais permanente, pela frequentação mútua. Acostuma-se a considerar os objetos e a fazer comparaçóes; insensivelmente, adquirem-se ideias de mérito e beleza, que produzem sentimentos de preferência." Eis a inscriçăo das primeiras festas no Discurso sobre a desigualdade: "[...] acostuma-se a reunir-se diante das cabanas ou em torno de uma grande árvore: o canto e a dança, verdadeiros filhos do amor e do lazer, tornam-se a distraçáo, ou melhor, a ocupação dos homens e das mulheres ociosos e agrupados." (ROUSSEAU, OC III, 1964, p. 169). Essa passagem anuncia o nascimento do amor, assim como da inveja, ciúmes etc. Uma paixão amorosa um tanto quanto diferente do "amor conjugal" da "pequena sociedade" familiar, pois marcada pelo sentimento de preferência surgido da comparação e pela exogamia (derivada da proibição - não nomeada nas páginas do Discurso - do incesto), isto é, pelas ligações entre famílias distintas. No entanto, a aproximaçáo entre os dois livros nâo dura muito, pois a diferença do Discurso sobre a desigualdade em relação ao Ensaio se faz ver, ao considerar as funções da linguagem e da música, no momento da festa primitiva. Esse momento, no Discurso, já testemunha o início da degradação das relaçôes interpessoais, pois mostra a música sendo mobilizada para atrair a atenção e a preferência do outro, angariando seu olhar e estima, servindo para impressionar os outros; ao passo que, no Ensaio, a linguagem surgida do encontro entre os dois sexos reflete autenticamente as disposiçóes passionais interiores e serve para expressar os sentimentos (COLE, 2004, p. 117-118).

${ }^{13}$ A teoria da piedade desenvolvida no Ensaio é distinta da apresentada no Discurso sobre a desigualdade. No Discurso, a piedade natural aparece como irrefletida ou pré-reflexiva. Essa concepção de piedade estaria ausente ou mesmo excluída do Ensaio, já que a noção de piedade precisa aí ser despertada pela imaginação e por certas luzes. O descompasso entre os livros desaparece em parte, se considerarmos que, em ambos, a piedade é encarada como a fonte das virtudes sociais. Muitos comentadores discutiram esse descompasso e a origem das afeiçôes sociais (Starobinski, Derrida, Goldschmidt, Charrak etc.). Seria aqui necessária uma comparação rigorosa entre as noçôes de piedade e amor de si apresentadas no Discurso, no Ensaio e, também, no Emílio, e suas relaçôes com a origem das virtudes sociais. Não obstante essa necessidade, tal tarefa ultrapassa os limites estabelecidos para este artigo. 
aquilo que nos interessa. [...] aplicai essas ideias aos primeiros homens, verás o motivo de sua barbárie. Sempre vendo táo somente o que estava à sua volta, nem mesmo isso conheciam, sequer conheciam a si próprio". (ROUSSEAU, OC V, 1995, p. 395-396).

São essas reflexốes que estão em jogo nas primeiras festas. $\mathrm{O}$ leitor precisa atentar para essa teoria do conhecimento e da piedade, a fim de melhor compreender a mudança que ocorre quando do encontro dos dois sexos nas fontes de água. Eles começaram a fazer comparaçóes a partir dos novos objetos (ou pessoas) que passaram a afetar seus sentidos. Com isso, algumas luzes entraram em cena, fazendo com que deixassem de lado sua primeira "ferocidade" atribuída à fraqueza e à ignorância e passassem a se entregar à paixão amorosa.

É possível então afirmar que, de acordo com a teoria de Rousseau, a sociedade, a língua e os laços morais nascem apenas a partir das trocas entre membros de famílias distintas, isto é, da proibição do incesto. Antes das primeiras festas, não havia a proibição do incesto e a humanidade era indiferente a ele: "[...] cada família bastava-se a si mesma e perpetuava-se unicamente pelo sangue.” Enquanto o incesto era permitido, não havia paixão amorosa e as relaçôes sexuais se limitavam às necessidades que concerniam ao bem-estar físico, sendo fundamentalmente determinadas por inclinaçóes naturais, hábitos, instintos ou apetites. Essa não-proibição é interrompida a partir da festa. É nesse momento que se pode localizar a fenda que separa natureza e cultura. A proibição do incesto é o elemento que revela a instauração da cultura e, portanto, representa também a origem da paixão, da preferência, da sociedade e das línguas. Não por outra razão, só depois de haver a proibição do incesto é que se pode falar em sociedade e em ordem moral.

A interdição permite a passagem do fato natural (a consanguinidade) ao fato social (a aliança). O elemento fundamental que nos interessa e que merece ser destacado é o seguinte: a esfera cultural e/ou social é instaurada concomitantemente à proibição do incesto e ao estabelecimento do regime de trocas entre diferentes famílias. O mérito de Rousseau reside no fato de ter percebido a função socializante que a interdição do incesto impóe às famílias, já que, com a regra de interdição do incesto, aparece necessariamente outra, a saber, a exogamia. A necessidade de buscar parceiros/parceiras fora do raio da consanguinidade se mostra como o elemento fundamental para possibilitar a interação entre as famílias e, por conseguinte, a amarração do 
tecido social para além dos limites familiares. Se, por um lado, o Discurso sobre a desigualdade evidencia como se dá o comércio e as ligaçóes entre as famílias, por outro, somente no Ensaio essa relação é encarada explicitamente como a contrapartida da proibição do incesto.

Na teoria de Lévi-Strauss, é a proibição do incesto que faz com que haja trocas entre os grupos e ela se dá concomitantemente à exogamia. Segundo ele, dessa vez, no livro $O$ olhar distanciado, 1983, a proibição do incesto

[...] não permite às famílias que perpetuem senão numa rede artificial de proibiçõos e obrigaçôes. É somente aí que se pode situar a passagem da natureza para a cultura, da condição animal para a condição humana e é apenas por aí que se pode compreender a sua articulação. (LÉVISTRAUSS, 1983, p. 83).

Ou seja, “[...] ao se opor às tendências separatistas da consanguinidade, a proibição do incesto consegue tecer redes de afinidades que dão às sociedades a armação sem a qual nenhuma delas se manteria.” (LÉVI-STRAUSS, 1983, p. 84$).{ }^{14}$

\section{Consideraçóes Finais}

Em um primeiro momento, vimos que, impossibilitados de abordar a passagem da natureza à cultura através de uma experiência real, Rousseau e Lévi-Strauss forjam mecanismos metodológicos para explicar essa passagem por meio de um plano ideal - no caso de Rousseau, a história conjectural. Posteriormente, analisamos que essa explicação encontra um terreno bastante fértil, quando eles recorrem à análise do interdito do incesto.

Com isso, vislumbramos melhor a função e a significação da proibição do incesto, nas páginas do Ensaio sobre a origem das linguas. Com ela, apreendemos de forma privilegiada o momento inatingível do quase presente na obra de Rousseau e fundamental para os estudos antropológicos: nem natureza, nem cultura, mas quase natureza e quase cultura, momento de passagem de uma estrutura à outra. A proibição do incesto marca o instante fundador da cultura, momento em que os homens deixam de seguir o mero instinto de procriação ou seu bem-estar físico - isto é, a inclinação natural,

\footnotetext{
14 "A proibição do incesto é a expressão negativa de uma lei de troca, a expressão parcial de um princípio universal de reciprocidade, a contrapartida necessária de uma instauração de laços sociais entre famílias." (DUMONT, 1997, p. 117).
} 
a tendência cega do mundo físico que "somente produzia um ato puramente animal" ou análogo à animalidade - e passam a se pautar por princípios morais, forjados no próprio tecido cultural a partir de uma convenção.

Com a proibição do incesto, forma-se o laço social propriamente dito e instaura-se a humanidade, uma vez que se efetua a passagem da ordem física à ordem moral - uma ordem que náo vem da natureza. A troca de parceiros entre famílias distintas (o contraponto positivo da regra negativa da proibição) assegura a humanidade da sociedade, isto é, sua não-animalidade, o que significa que a sociedade humana não pertence à ordem da natureza, mas à da cultura. Rousseau e Lévi-Strauss nos mostram que a sociedade humana se manifesta no universo da regra e da cultura, náo no universo da necessidade; no mundo da instituição, não no do instinto. Em suma, a proibição do incesto e, por conseguinte, a troca exogâmica de parceiros fundam a sociedade.

BANDERA, M. D. From nature to culture: the problem of the prohibition of incest in Rousseau’s anthropology. Trans/form/ação, Marília, v. 44, n. 1, p. 293-312, Jan./Mar., 2021.

\begin{abstract}
The dichotomy of the physical/moral world is characteristic in the French eighteenth century. It refers to the natural biological dimensions and moral dimensions of man. Many authors of the Enlightenment wished to retrace the conjectural history or the successive metamorphoses that led to the passage of the physical man to the moral man. This theme is also present in the work of Rousseau, being perceived and translated by Lévi-Strauss as the passage from nature to culture. The hypothesis we develop in this article is that the prohibition of incest - present in Rousseau's work - has a function and a signification very close to the reflections of Lévi-Strauss present in the Elementary Structures of Kinship. Like in Lévi-Strauss, this prohibition marks for Rousseau the beginning of the process of cultural formation, the founding instant of culture. It expresses in a privileged way the point by which cultural processes are distinguished from the natural sphere, the moment in which man stops following his mere instinct and begins to respect socially constructed moral principles.
\end{abstract}

Keywords: Nature. Culture. Prohibition of incest. Rousseau. Lévi-Strauss.

\title{
REFERÊNCIAS
}

BANDERA, M. D. A perfectibilidade segundo Rousseau. Cadernos de Ética e Filosofia Política, v. 1, n. 34, p. 132-142, 25 jun. 2019. Disponível em: https://doi.org/10.11606/ issn.1517-0128.v1i34p132-142. Acesso em: 10 fev. 2020. 
CHANTELOUBE, I. La scène d'énonciation de Jean-Jacques Rousseau. Lyon: Université Moulin, 2003.

CHARRAK, A. Introduction. In: ROUSSEAU, J.-J. Émile ou de l'éducation. Paris: Flammarion, 2009.

CHARRAK, A. Le rôle des fictions dans la théorie de l'homme. In: BACHOFEN, B.; BERNARDI, B.; CHARRAK, A.; GUÉNARD, F. Philosophie de Rousseau. Paris: Classiques Garnier, 2014. p. 145-154.

CHARRAK, A. Rousseau: de l'empirisme à l'expérience. Paris: J. Vrin, 2013.

COLE, C. From silence to society: the conflicting musical visions of Rousseau's Discours sur l'origine de l'inégalité and Essai sur l'origine des langues. In: DAUPHIN, C. (org.).

Musique et langage chez Rousseau. Studies on Voltaire and the eighteenth century. Oxford: Voltaire Foundation, 2004.

DERRIDA, J. De la Grammatologie. Paris : Éditions de Minuit, 1967.

DUMONT, L. Groupes de filiation et alliance de mariage: introduction à deux théories d'anthropologie sociale. Paris: Éditions Gallimard, 1997.

EHRARD, J. L'idée de nature en France dans la première moitié du XVIIIe siècle. Paris: Albin Michel, 1994.

LÉVI-STRAUSS, C. (1949). Les Structures élémentaires de la parenté. Paris: Mouton. 1967.

LÉVI-STRAUSS, C. Le regard éloigné. Paris: Plon, 1983.

LÉVI-STRAUSS, C. (1962). Le Totémisme aujourd'hui. In : LÉVI-STRAUSS, C. Euvres. Paris: Éditions Gallimard, 1995 (Bibliothèque de la Pléiade).

LÉVI-STRAUSS, C. (1962). Jean-Jacques Rousseau, fondateur des sciences de l'homme. In: LÉVI-STRAUSS, C. Anthropologie structurale deux. Paris: Plon, 1996.

MAUPERTUIS (1745, 1752). Vénus Physique : suivie de la Lettre sur le progrès des sciences. Paris : Édition Aubier-Montaigne, 1980.

ROUSSEAU, J.-J. Euvres Complètes de Jean-Jacques Rousseau. Ed. Bernard Gagnebin e Marcel Raymond. Paris: Gallimard, 1959-1995. 5 volumes. (Col. Bibliothèque de la Pléiade).

ROUSSEAU, J.-J. Euvres Complètes de Jean-Jacques Rousseau. Édition thématique du Tricentenaire. Sous la direction de Raymond Trousson et Frédéric S. Eigeldinger. Paris: Slatkine/ Honoré Champion, 2012. Version électronique: http://rousseau.slatkine.com/ Acesso em: 10 fev. 2020.

STAROBINSKI, J. Jean-Jacques Rousseau: a transparência e o obstáculo, seguido de sete ensaios sobre Rousseau. Tradução de Maria Lúcia Machado. São Paulo: Companhia das Letras, 1991. 
BANDERA, M. D.

WOKLER, R. Anthropology and conjectural history in the enlightenment. In: FOX, C.; PORTER, R.; WOKLER, R. (ed.). Inventing human science: eighteenth-century domains. Berkeley, Los Angeles, London: University of Califonia Press, 1995, p. 31-52.

Recebido: 20/5/2020

Aceito: $14 / 7 / 2020$ 